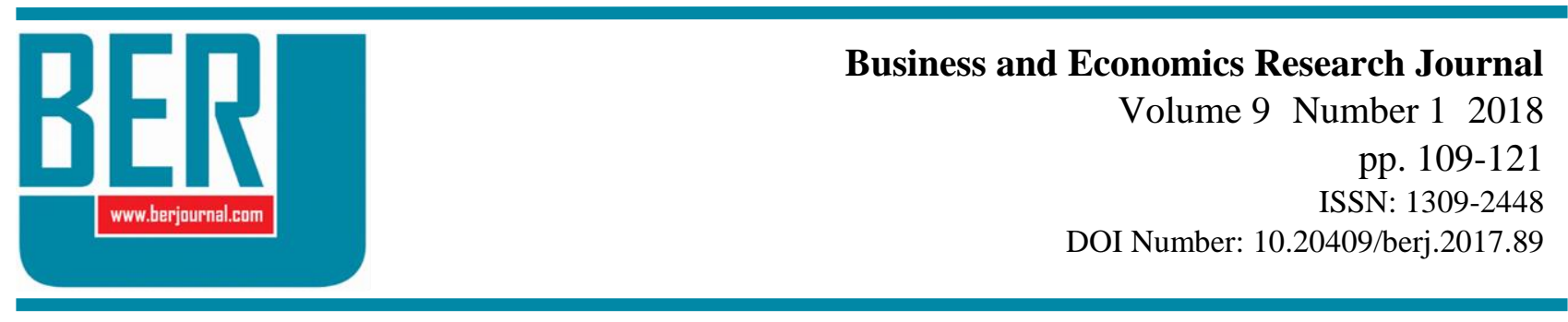

\title{
BIST 30 Endeksi ile MSCI Gelişmekte Olan Piyasalar Endeksinin Küresel Kriz Öncesi ve Sonrası Eşbütünleşme Analizi
}

\author{
Hakkı Öztürk ${ }^{\mathrm{a}}$
}

\begin{abstract}
Öz: Bu çalışma BIST 30 endeksi ve MSCl gelişmekte olan piyasalar endeksi arasındaki eşbütünleşmeyi Ocak 2003'den Temmuz 2017'e kadar Johansen eşbütünleşme testi uygulayarak incelemektedir. MSCl gelişmekte olan piyasalar endeksi Morgan Stanley Capital International tarafindan oluşturulmuş ve 24 tane gelişmekte olan ülkedeki borsa endekslerini içermektedir. MSCl endeksi gelişmekte olan piyasalarda kıyaslama ölçütü olarak kabul edildiğinden, bu endeksin Borsa istanbul ile olan ilişkisi portföy yöneticileri için çok önemlidir. Aynı zamanda, Borsa Istanbul ve gelişmekte olan piyasalar arasında uzun vadeli ilişkideki son küresel finans krizinin etkisini analiz etmek için, tüm dönem kriz öncesi ve kriz sonrası dönemlere ayrılmıştır. Tüm dönem için, Borsa Istanbul ve MSCl gelişmekte olan piyasalar endeksi arasında anlamlı uzun vadeli bir ilişki var iken, kriz öncesi dönemde endeksler arasında eşbütünleşme ilişkisi yoktur. Ancak, Borsa Istanbul ve $\mathrm{MSCl}$ endeksi kriz sonrasında eşbütünleşiktir ve uzun vadede beraber hareket etmektedirler. Bu durum, son yıllarda finansal piyasalardaki artan küreselleşmeden dolayı, söz edilen piyasalar arasında portföy çeşitlendirmesinin sınırlı faydaları olduğunu gösterebilir.
\end{abstract}

Anahtar Sözcükler: Borsa İstanbul, MSCl Gelişmekte Olan Piyasalar Endeksi, Eşbütünleşme, Johansen Testi, Küresel Finansal Kriz

JEL Sınıflandırması: C58, G01, G11,G19

\section{Cointegration Analysis of BIST 30 Index and MSCI Emerging Markets Index: Pre and Post Global Financial Crisis}

\begin{abstract}
This study examines the cointegration between BIST 30 index and MSCl emerging market index from January 2003 to July 2017 by employing Johansen cointegration test. The MSCl emerging markets index is created by Morgan Stanley Capital International and consists of indices from 24 emerging countries. Since the $\mathrm{MSCl}$ index is considered as a benchmark in emerging markets, the relationship between Borsa Istanbul and this index is very important for portfolio managers. In addition, to analyze the long-term impact of the recent global financial crisis between Borsa Istanbul and emerging markets, the sample period is divided into two sub-periods : pre and post crisis. For the whole period, there does exist a significant long term relation between Borsa Istanbul and MSCl emerging market index while there is no evidence of cointegration in the pre-crisis period. However, the results for the post crisis period indicate that Borsa Istanbul and $\mathrm{MSCl}$ index are cointegrated that means they move together in the long run. This may suggest that there are limited benefits for portfolio diversification between these markets due to increased globalization of financial markets in recent years.
\end{abstract}

Keywords: Istanbul Stock Exchange, MSCI Emerging Markets Index, Cointegration, Johansen Test, Global Financial Crisis JEL Classification: C58, G01, G11,G19

aAsst. Prof., PhD., Bahcesehir University, Faculty of Economics, Administrative and Social Sciences, International Finance Department, Istanbul, Turkiye, hakki.ozturk@eas.bau.edu.tr (ORCID ID: 0000-0003-4546-838X) 


\section{Giriş}

Türkiye'nin 1980 yılı ile birlikte serbest piyasa ekonomisine geçmesi, 1990 yılları ile başlayan finansal küreselleşme ve aynı zamanda bilgisayar ve internet teknolojisinde gelişmeler fon ve portföy yatırımlarında maliyetlerin düşmesini sağlamıştır. Bunun sonucu olarak yatırımcıların uluslararası piyasalarda yatırım yapması daha kolay hale gelmiştir. Küreselleşme ile birlikte, son yıllarda yabancı portföy ve fonların dünyadaki herhangi bir piyasaya son derece hızı ve rahat yatırım yapabilmeleri sayesinde ülkeler arası fon akışları ciddi oranda artmıştır. Aynı zamanda bu süreç, menkul kıymet çeşitliliğini arttırmış, portföy çeşitlendirmesi ve portföy yönetimi daha büyük önem kazanmıştır.

Küreselleşmenin sonucu olarak dünyadaki finansal piyasalar birbirine daha çok entegre (bütünleşmiş) hale gelmeye başlamışlardır. Entegrasyon süreci ile birlikte finansal piyasaların birlikte hareket etmesi artmış ve portföy teorisinin temeli olan çeşitlendirmenin faydaları tartş̧lır hale gelmiştir. Gelişmiş ülkelerde ortaya çıkan finansal krizlerle birlikte yatırımcılar daha yüksek getiri arayışına girmişlerdir. Bundan dolayı da gelişmiş olan ülkelere göre daha yüksek getiri sunan gelişmekte olan ülkelere daha çok yatırım yapmayı seçmişler ve uluslararası portföy çeşitlendirmesinden faydalanmak istemişlerdir. Yabancı fon ve portföy yöneticilerinin finansal bütünleşme ile beraber teorik olarak elimine edilmesi mümkün olmayan kendi ülkelerindeki sistematik riski, farklı ülkelere yatırım yaparak (uluslararası çeşitlendirme) azaltmak istemektedirler. Eğer yatırım yapılan farklı ülkelerdeki piyasalar beraber hareket etmeyip bağımsız hareket ettikleri takdirde bu uluslararası çeşitlendirme işe yarayabilir. Ancak önceden de bahsedildiği üzere, son yıllarda zirve yapan küreselleşme ile birlikte finansal piyasaların birbirleriyle olan entegrasyonu uluslararası çeşitlendirmeyi sınırlı hale getirmiştir. Başka bir ifade ile, çeşitlendirmenin (diversification) faydalı olabilmesi için uluslararası finansal piyasalarının birbirleriyle olan ilişkilerinin zayıf olması ve uluslararası piyasaların bütünleşmiş olmaması gereklidir. Bu yüzden, yerli ve yabancı yatırımcılar için farklı ülke borsaları arasındaki uzun vadeli ilişkilerin belirlenmesi portföy yönetimi ve çeşitlendirilmesi açısından büyük önem arz etmektedir

Bu çalışmada Borsa İstanbul'daki BIST 30 endeksinin Morgan Stanley Capital International tarafindan hesaplanan gelişmekte olan ülkeler endeksi (MSCI Emerging Market Index-MXEF) ile uzun vadeli ilişkisi 20032017 yılları arasında hem küresel finansal kriz öncesi hem de kriz sonrası Johansen eşbütünleşme (kointegrasyon) analizi ile test edilmektedir. Çalışmanın ikinci bölümünde literatür taraması, üçüncü bölümde veri ve kullanılan ekonometrik yöntem ve son bölümde sonuç kısmı yer almaktadır.

\section{Literatür}

En çok atıf almış ve yapılan ilk çalışmalardan biri olan Kasa (1992), Ocak 1974-Ağustos 1990 dönemi için aylık ve 3 aylık veri kullanarak yaptı̆ı̆ Johansen eşbütünleşme analizinde ABD, Japonya, İngiltere, Almanya ve Kanada borsaları arasında uzun vadeli ilişkinin olduğu sonucuna varmıştır. Aynı zamanda benzer sonuçlar; Chou; Ng ve Pi (1994) tarafindan Temmuz 1976-Aralık 1989 dönemi için haftalık veri kullanılarak yapılan Johansen eşbütünleşme analizinde de bulunmuştur. Bu çalışmanın sonuçları da, Amerika, Kanada, İngiltere, Fransa ve Almanya ve Japonya hisse senetleri piyasaları arasında eşbütünleşme olduğunu ve sermaye piyasalarının küreselleşmesinin arttğını göstermiştir.

Worthington ve Higgs (2007), Avrupa piyasaları için yaptıkları çalışmada, 1990-2006 dönemi için Avustralya, Belçika, Danimarka, Fransa, Almanya, Yunanistan, İrlanda, İtalya, Hollanda, İspanya ve İngiltere arasında uzun vadeli ilişki olduğu sonucunu bulmuşlardır. Erdinc ve Milla (2009) tarafindan yapılan bir diğer çalışmada, 1991-2006 yılları arasında Fransa, Almanya, İngiltere ve MSCl dünya hisse piyasaları endeksi kullanılmış ve söz edilen piyasalar arasında uzun vadeli bir ilişkinin olduğu sonucuna varılmıştır.

Gilmore ve McManus (2003), Temmuz 1995-Mart 2002 yılları arasında Johansen eşbütünleşme analizini kullanarak yaptıkları çalışmada, Alman hisse senetleri piyasasının göstergesi olan DAX endeksini ve Merkez Avrupa hisse senetleri piyasasını temsilen ise IFCl endekslerini kullanmışlardır. Uzun dönemde tek tek veya grup olarak herhangi bir ilişkinin olmadığı sonucuna varmışlardır.

Khanna (2016) tarafindan gelişmekte olan piyasalardan Hindistan hisse senetleri piyasası için yapılan bir başka çalışmada, Hindistan piyasasının İngiltere ve Japon hisse senetleri piyasalarıyla ilişkisi 2007-2008 
krizi öncesi ve sonrası günlük ve haftalık veri kullanılarak incelenmiştir. Kriz öncesi Japonya ve İngiltere hisse senetleri piyasası Hindistan piyasası ile bütünleşik iken kriz sonrası Hindistan sadece İngiltere piyasasından etkilenmiştir. Bir diğer gelişmekte piyasa olan Pakistan için Ali, Butt ve Rehman(2011) tarafindan yapılan çalışmada, 1998-2008 dönemi için Pakistan hisse senetleri piyasasının İngiltere, Amerika, Tayvan, Malezya, Singapur piyasaları ile ilişkide olmadığı ancak Hindistan, Çin, Japonya ve Endonezya ile beraber hareket ettiği sonucu elde edilmiştir.

Nashier (2015) tarafindan gelişmekte olan BRICS (Brezilya, Rusya, Hindistan, Çin ve Güney Afrika) ülkeleri ile gelişmiş piyasalar Amerika ve İngiltere için 2004-2013 yılları arasındaki veri kullanılarak yapılan araştırmada, korelasyon test sonuçlarına göre piyasalar arasında bütünleşme olduğu ve Johansen eşbütünleşme analizi uygulandığında Brezilya- Hindistan, Güney Afrika-İngiltere, Rusya-Güney Afrika ve Rusya-İngiltere arasında eşbütünleşme olduğu sonucu çıkmıştır. Aynı zamanda çok değişkenli testlerde Rusya, Güney Afrika ve İngiltere hisse senetleri piyasalarının ilişkide olduğu görülmüştür. Dolayısıyla yatırımcıların gelişmiş olan piyasalardan gelişmekte olan BRICS ülkeleri piyasalarına yatıı yapmalarının kazanç sağlamayacağı ve çeşitlendirme yapmanın limitli faydaları olabileceği sonucuna varılmıştır.

Kenourgios ve Samitas (2003), 1998-2000 yılları arasında Yunanistan ile Belçika, İtalya, Portekiz, Almanya, Fransa arasında eşbütünleşme tespit edemezken sadece Yunanistan ve İngiltere arasında eşbütünleşme tespit etmişlerdir.

Narayan ve Russell (2004), 1960-2003 yılları arasında Avustralya borsası ve Kanada-italya-Japonyaİngiltere arasında uzun vadeli bir ilişki olduğunu sonucunu bulmalarına rağmen Avustralya borsası ve FransaAlmanya-ABD borsaları ile eşbütünleşme ilişkisine rastlanmamıştır.

Türkiye için yapılan çalışmaların bir kısmı da aşağıda özetlenmektedir.

Sevüktekin ve Nargeleçekenler (2008) tarafindan yapılan çalışmada Dow Jones, Nasdaq ve S\&P 500 endeksleri ile Borsa İstanbul arasındaki uzun vadeli ilişki Johansen eşbütünleşme testine göre incelenmiştir. Bulgulara göre Amerika'daki borsalar ve Borsa İstanbul arasında uzun dönemli bir ilişki vardır. Borsa İstanbul'un en yüksek reaksiyonu Dow Jones endeksine gösterdiği belirtilmiştir. Benzer sonuçlar, Bulut ve Özdemir'in(2012) yapttğı araştırmada da bulunmuştur. 2001-2010 dönemi için yapılan araştırmanın sonucuna göre, Borsa İstanbul ve Dow Jones uzun dönemde birlikte hareket etmektedir yani eşbütünleşiktir .

Vuran (2010) yapttğı çalışmada BIST 100 endeksi ile geliş̧miş ve gelişmekte olan hisse senedi borsa endeksleri arasındaki uzun vadeli ilişkiyi Johansen eşbütünleşme analizi ile 2006- 2009 döneminde test etmiştir. Bulgulara göre, BIST 100 endeksi ile İngiltere, Almanya, Brezilya, Arjantin ve Meksika ülke endekslerinin uzun vadede ilişki içinde olduğu tespit edilmiştir.

Borsa İstanbul ile $\mathrm{MSCl}$ gelişmekte olan ülke piyasaları endeksi arasındaki ilişkiyi incelemek için Yıldız ve Aksoy (2014) tarafindan yapılan bir diğer çalışmada, Ocak 1990-Aralık 2011 döneminde eşbütünleşme Engle- Granger yöntemi ile incelenmiştir. Bulgulara göre, BIST ve $\mathrm{MSCl}$ endeksinin eşbütünleşik olduğu ve uzun dönemde serilerin birlikte hareket ettikleri görülmüştür. Bundan dolayı, bu endeksler söz konusu dönem boyunca etkin portföy çeşitlendirmesi için uygun firsatlar sunmamaktadır.

Boztosun ve Çelik (2011), BIST 100 endeksi ve Avusturya, Belçika, Fransa, Almanya, Hollanda, Norveç, İspanya, İsveç, İsviçre ve İngiltere piyasası arasındaki uzun dönemli ilişkiyi Ocak 2002 ile Aralık 2009 dönemi için Johansen-Jeselius eşbütünleşme testi ile analiz etmişlerdir. Sonuçlara göre, BIST 100 endeksinin Norveç, Hollanda, Belçika, Almanya ve İngiltere ile eşbütünleşme ilişkisi olmasına rağmen BIST 100 endeksi ile Fransa, Avusturya, İsviçre, İsveç ve İspanya arasında ise eşbütünleşme ilişkisi mevcut değildir.

Akel (2015) yaptığı çalışmada Morgan Stanley tarafindan kırılgan beşli olarak tanımlanan Brezilya, Endonezya, Güney Afrika, Hindistan ve Türkiye arasındaki ilişkiyi Kasım 2000 ve Aralık 2013 dönemi için Johansen eşbütünleşme testine göre incelemiştir. Sonuçlara göre bu beşülkenin uzun dönemli bir ilişkisinin olduğu tespit edilmiştir. 


\section{Veri Seti ve Ekonometrik Yöntem}

Bu çalışmada Borsa İstanbul'daki BIST 30 endeksinin, gelişmekte olan ülkelerin borsa endeksi göstergesi olan MSCI EM endeksi ile uzun dönemli ilişkisi Ocak 2003- Temmuz 2017 yılları arasında hem küresel kriz öncesi hem de küresel kriz sonrası Johansen eşbütünleşme analizi kullanılarak araştrılmıştır. BIST 30 endeksinin uzun dönemde gelişmekte olan piyasalarla nasıl bir ilişki içinde olduğu oldukça önemlidir.

Türkiye'den piyasa değerleri, hacim ve likiditesi en yüksek hisselerin yer aldığı BIST 30 endeksi kullanılmıştır. BIST 30 endeksinin seçilmesinin nedeni, bu endeksteki hisse senetlerinin yabancı yatırımcılar tarafindan en çok işlem yapılan hisse senetleri olmalarıdır.

Diğer endeks ise, Morgan Stanley Capital International tarafindan 1 Ocak 2001 tarihinde hesaplanmaya başlanan gelişmekte olan piyasalar endeksidir ( $\mathrm{MSCl}$ Emerging Markets Index). MSCl gelişmekte olan ülkeler endeksinde 24 tane ülkenin borsa endeksleri yer almaktadır. Bunlar, Brezilya, Çin, Şili, Kolombiya, Çek Cumhuriyeti, Mısır, Yunanistan, Macaristan, Hindistan, Endonezya, Kore, Malezya, Meksika, Pakistan, Peru, Filipinler, Polonya, Rusya, Katar, Güney Afrika, Tayvan, Tayland, Türkiye ve Birleşik Arap Emirlikleri'dir. Bu ülkelerin endeksteki ağırlıkları da şöyledir: Çin \%29,68, Güney Kore: \%15,66, Tayvan: \% 11,83, Hindistan \%8,72, Brezilya \%7.08, Diğer ülkeler : \%27.03. MSCI EM endeksi hesaplanırken en çok kullanılan endeks hesaplama yöntemlerinden biri olan ve BIST 30 endeksinin de hesaplanmasına temel oluşturan piyasa değeri ağırlıklı endeks (market value weigthed index) hesaplama yöntemi kullanılır. Ülke ağırlıklarına göre seçilen toplam 838 hisse senetlerinin fiili dolaşımdaki hisse sayıları (free float shares) ile hisse senetlerinin fiyatları çarpılarak MSCI EM endeksi hesaplanır. Endeks her ülkedeki fiili dolaşımda olan hisse senetlerinin piyasa değerlerinin yaklaşık olarak \%85'ini kapsar. $\mathrm{MSCl}$ gelişmekte olan piyasalar endeksi hem Türkiye'de hem de uluslararası piyasalarda fon ve portföy yöneticileri tarafindan sıklıkla takip edilen ve kıyaslama ölçütü (benchmark) olarak kullanılan bir endekstir. (MSCI Raporları, 2017)

Çalışmada kullanılan endeksler ve kodları aşağıdaki Tablo 1'de gösterilmiştir.

Tablo 1. Endeksler ve Kodları

\begin{tabular}{|l|l|}
\hline & \multicolumn{2}{|c|}{ Kodu } \\
\hline BIST 30 Endeksi & XU30 \\
\hline MSCI Gelişmekte Olan Ülkeler Endeksi & MXEF \\
\hline
\end{tabular}

Veri seti söz edilen endekslerin Ocak 2003- Temmuz 2017 arasındaki ay sonu kapanış değerleridir. Veriler bloomberg programından indirilmiştir. Öncelikle tüm dönem için yapılan Johansen eşbütünleşme analizi, daha sonra küresel kriz öncesi ve küresel kriz sonrası dönemlere ayrılıp, XU30 endeksinin kriz öncesi ve kriz sonrası MXEF endeksi ile nasıl hareket ettiği incelenmiştir.

Öncelikle aylık kapanış fiyatlarının logaritmaları alınarak logaritmik seriler elde edilmiştir. Aynı zamanda logaritmik serilerin entegrasyon seviyeleri incelenmiştir. Serilerin durağan olup olmadığını anlamak için Augmented Dickey Fuller ve Philips-Peron testlerinden faydalanılmıştır. Eğer bir zaman serisi seviye bazında birim kök içerip ve durağan değilse ancak birinci farkları alındıktan sonra durağanlaşıyorsa bu serinin entegrasyon seviyesinin I(1) olduğu söylenir. Serilerin entegrasyon seviyesi I(1) olarak belirlendikten sonra seriler arasındaki uzun vadeli ilişkiyi incelemek için Johansen eşbütünleşme analizi yapılabilir(Ali, Butt ve Rehman, 2011: 398).

Birim kök testleriyle serilerin durağan olup olmadığı anlaşıldıktan sonra, optimal gecikme uzunluğunun belirlenmesi için VAR (Vector Autoregressive Model) analizi uygulanmış ve seriler için optimal gecikme uzunlukları hesaplanmıştr. Gecikme uzunlukları belirlendikten sonra, seriler arasındaki uzun vadeli ilişkiyi incelemek için Johansen eşbütünleşme analizine geçilmiştir. 
H. Ozturk

\subsection{Tüm dönem İçin Yapılan Analiz ve Ampirik Bulgular}

Ocak 2003 ile Temmuz 2017 arasında aylık olarak incelenen XU30 ve MXEF endekslerinin logaritmik serilerinin özet istatistikleri aşağıdaki Tablo 2'de gösterilmiştir.

Tablo 2. Özet İstatistikler

\begin{tabular}{|l|c|c|}
\hline & LOGXU30 & LOGMXEF \\
\hline Ortalama & 4.7656 & 2.9074 \\
\hline Ortanca & 4.8355 & 2.9667 \\
\hline En Yüksek & 5.1207 & 3.1262 \\
\hline En Düşük & 4.0710 & 2.4350 \\
\hline Std. Sapma & 0.2405 & 0.1519 \\
\hline Çarpıklık & -1.0223 & -1.2867 \\
\hline Basıklık & 3.3534 & 3.8634 \\
\hline Jarque-Bera & 31.3970 & 53.7294 \\
\hline Gözlem & 175 & 175 \\
\hline
\end{tabular}

*Jarque- Bera istatistiği serilerin normal dağılmadığını gösterir.

Tablo 3'de ise, seriler arasındaki korelasyon katsayısı gösterilmektedir. XU30 ve MXEF endeksleri arasındaki korelasyon katsayısı 0,87'dir.

Tablo 3. Endeksler Arasındaki Korelasyon

\begin{tabular}{|c|c|c|}
\hline & LOGXU30 & LOGMXEF \\
\hline LOGXU30 & 1 & 0.8789 \\
\hline LOGMXEF & 0.8789 & 1 \\
\hline
\end{tabular}

\subsection{Birim Kök Testleri}

Ocak 2003 ve Temmuz 2017 dönemi için XU30 ve MXEF endekslerinin logaritmik serilerinin birim kök testi sonuçları Tablo 4 ve Tablo 5 'de verilmiştir.

Tablo 4. Augmented Dickey Fuller Birim Kök Testi Sonuçları (Düzey)

Sabit Terimli

\begin{tabular}{|l|c|c|c|c|}
\hline ADF (Düzey) & t-istatistik & Olasılık & t-istatistik & Olasılık \\
\hline LOGXU30 & -2.1939 & 0.2093 & -2.8759 & 0.1730 \\
\hline LOGMXEF & -3.0940 & 0.0288 & -2.8776 & 0.1724 \\
\hline
\end{tabular}


Tablo 5. Philips-Peron Birim Kök Testi Sonuçları (Düzey)

Sabit Terimli

\begin{tabular}{|l|c|c|c|c|}
\hline $\begin{array}{l}\text { Phillips-Perron } \\
\text { (Düzey) }\end{array}$ & t-istatistik & Olasılık & t-istatistik & Olasılık \\
\hline LOGXU30 & -2.1939 & 0.2093 & -2.8739 & 0.1736 \\
\hline LOGMXEF & -2.8631 & 0.0519 & -2.6695 & 0.2507 \\
\hline
\end{tabular}

Tablo 4 ve Tablo 5 'den anlaşıldığı üzere hem ADF hem de Phillips-Perron birim kök testi sonuçlarına göre seriler \%1 anlamlılık düzeyinde birim kök içermektedir ve durağan değildir. Serilerin birinci farkları alınarak yapılan birim kök testi sonuçları da Tablo 6 ve Tablo 7'de verilmiştir.

Tablo 6. Augmented Dickey Fuller Birim Kök Testi Sonuçları (1. Fark)

Sabit Terimli

Sabit Terim ve Trendli

\begin{tabular}{|l|c|c|c|c|}
\hline ADF (1. fark) & t-istatistik & Olasılık & t-istatistik & Olasılık \\
\hline D(LOGXU30) & -13.8088 & 0.0000 & -13.8422 & 0.0000 \\
\hline D(LOGMXEF) & -10.6395 & 0.0000 & -10.7476 & 0.0000 \\
\hline
\end{tabular}

Tablo 7. Philips-Peron Birim Kök Testi Sonuçları (1. fark)

Sabit Terimli

Sabit Terim ve Trendli

\begin{tabular}{|l|c|c|c|c|}
\hline Phillips-Perron (1. fark) & t-istatistik & Olasılık & t-istatistik & Olasılık \\
\hline D(LOGXU30) & -13.7965 & 0.0000 & -13.8395 & 0.0000 \\
\hline D(LOGMXEF) & -10.8273 & 0.0000 & -10.87638 & 0.0000 \\
\hline
\end{tabular}

Serilerin birinci farkı alınarak hem sabit terimli hem de sabit terim ve trendli yapılan birim kök testlerinde ADF ve PP'ye göre seriler birim kök içermemektedir dolayısıyla durağandır. Durağanlık testleri yapılırken Eviews7 programında gecikme uzunluğu Schwartz Bilgi Kriteri'ne göre program tarafindan otomatik olarak seçilmiştir. Maksimum gecikme uzunluğu on iki alınmıştır.

Uygulanan birim kök testi sonuçlarına göre, serilerin düzeyde durağan olmadığı ancak serilerin birinci farkları alınarak tekrarlanan testlere göre endeks değerlerinin logaritmik serilerinin durağan olduğu anlaşılmaktadır. Serilerin aynı dereceden bütünleşik (entegre) oldukları I(1) sonucuna varılmıştır. Ancak serilerin aynı dereceden bütünleşik olmaları uzun dönemde her zaman birlikte hareket ettikleri anlamına gelmemektedir. Durağan olmayan iki ya da daha fazla seri arasında uzun dönemde bir ilişki olup olmadığı Johansen eşbütünleşme testi ile belirlenmektedir (Akel, 2015: 87). 


\subsection{Johansen Eşbütünleşme Analizi Sonuçları}

Johansen eşbütünleşme analizine geçilmeden önce optimal gecikme uzunluğunun belirlenmesi için VAR (Vector Autoregressive Model) analizi uygulanmış ve seriler için optimal gecikme uzunlukları hesaplanmıştır. Aşağıdaki Tablo 8, XU30 ve MXEF endeksleri için VAR analizi sonuçlarını göstermektedir.

Tablo 8. VAR Gecikme Uzunluğu Seçim Kriteri

\begin{tabular}{|c|c|c|c|c|c|}
\hline $\begin{array}{c}\text { Gecikme } \\
\text { Uzunluğu }\end{array}$ & LR & FPE & AIC & SC & HQ \\
\hline 0 & NA & 0.0002 & -2.7920 & -2.7547 & -2.7769 \\
\hline 1 & 966.6305 & $6.07 \mathrm{e}-07$ & -8.6382 & $-8.5262^{*}$ & $-8.5927^{*}$ \\
\hline 2 & $12.3703^{*}$ & $5.90 \mathrm{e}-07^{*}$ & $-8.6667^{*}$ & -8.4799 & -8.5909 \\
\hline 3 & 2.2960 & $6.11 \mathrm{e}-07$ & -8.6331 & -8.3717 & -8.5270 \\
\hline 4 & 3.8693 & $6.25 \mathrm{e}-07$ & -8.6097 & -8.2736 & -8.4733 \\
\hline 5 & 4.3344 & $6.38 \mathrm{e}-07$ & -8.5896 & -8.1788 & -8.4229 \\
\hline 6 & 3.1578 & $6.56 \mathrm{e}-07$ & -8.5622 & -8.0767 & -8.3651 \\
\hline 7 & 1.7690 & $6.80 \mathrm{e}-07$ & -8.5259 & -7.9658 & -8.2986 \\
\hline 8 & 1.4782 & $7.07 \mathrm{e}-07$ & -8.4879 & -7.8531 & -8.2302 \\
\hline
\end{tabular}

Optimal gecikme uzunluğu seçim kriterinde maksimum gecikme uzunluğu sekiz seçilmiştir (Boztosun ve Çelik, 2011 : 158). Optimal gecikme uzunluklarını belirlemek için; LR (sequential modified LR test statistic), FPE ( Final prediction error), AIC (Akaike information criterion), SC ( Schwarz information criterion) ve HQ (Hannan-Quinn information criterion) kriterleri kullanılmıştır. Bu bilgi kriterlerine göre belirlenen optimal gecikme uzunlukları * işareti ile Tablo 8'de gösterilmiştir. Beş tane kriterden optimal gecikme uzunluğu üç tanesinde (LR, FPE ve AIC) iki olarak belirlenmiştir. İki çıkan optimal gecikme uzunluğunu, düzey değerleri kullanıldığı için Johansen testinde bir azaltarak "bir" gecikme ile modele dahil etmek gerekir (Eviews5, usersguide: 727).

Ocak 2003- Temmuz 2017 döneminde XU30 ve MXEF endeksleri arasında herhangi bir eşbütünleşme olup olmadığını araştırmak için yapılan Johansen eşbütünleşme analizi sonuçları aşağıdaki Tablo 9'da verilmiştir.

Tablo 9. Tüm Dönem İçin Johansen Eşbütünleşme Analizi Sonuçları (1 Gecikmeli)

\begin{tabular}{|l|c|c|c|c|c|c|}
\hline Ho & $\begin{array}{c}\text { İz (Trace) } \\
\text { İstatistiği }\end{array}$ & $\begin{array}{c}\mathbf{0 . 0 5} \\
\text { Kritik } \\
\text { Değer }\end{array}$ & Olasılık & $\begin{array}{c}\text { Maksimum } \\
\text { Özdeğer } \\
\text { İstatistiği }\end{array}$ & $\begin{array}{c}\mathbf{0 . 0 5} \\
\text { Kritik } \\
\text { Değer }\end{array}$ & Olasılık \\
\hline Koentegre Vektör Yoktur $(r=0)$ & 14.3462 & 15.4947 & 0.074 & 12.9346 & 14.2646 & 0.080 \\
\hline En Çok 1 Koentegre Vektör Vardır. $(r \leq 1)$ & 1.4116 & 3.8415 & 0.2348 & 1.4116 & 3.8415 & 0.2348 \\
\hline
\end{tabular}

Tablo 9'dan anlaşıldığı üzere hem iz (trace) istatistiğine göre hem de maksimum özdeğer istatistiğine göre \%10 anlamlılık düzeyinde XU30 ve MXEF endeksleri arasında herhangi bir eşbütünleşme vektörün bulunmadığını ifade eden sıfir hipotezi reddedilmiştir. İncelenen dönem için endeksler arasında eşbütünleşme ilişkisi mevcuttur. Endeksler arasında uzun dönemli bir ilişki olduğu sonucuna varılmıştır. 


\subsection{Küresel Kriz Öncesi Dönem için Yapılan Analizler}

Incelenen tüm dönem için XU30 ve MXEF endeksleri arasında Johansen eşbütünleşme illişkisi bulunmuştur. Ancak bu dönemi küresel kriz öncesi ve küresel kriz sonrası diye ayırarak tekrar eşbütünleşme analizlerini yapmanın faydalı olacağı düşünülmektedir.

2007 yılının Ağustos ayı finansal krizin başladığı tarih olarak seçilmiştir. Bu tarih, BNP Paribas'ın üç büyük hedge fonunun ciddi ödeme problemlerinin başladığı tarihtir (Yüksel ve diğerleri, 2017: 88).

Dolayısıyla kriz öncesi dönem Ocak 2003 - Temmuz 2007 ve kriz sonrası dönem de Ağustos 2007 Temmuz 2017 olarak seçilmiştir. XU30 endeksi ile MXEF endeksi arasında hem kriz öncesinde hem de kriz sonrasında eşbütünleşme ilişkisinin olup olmadığı önemlidir.

Kriz öncesi dönemde XU30 ve MXEF endekslerinin logaritmik serilerinin birim kök testi sonuçları Tablo $10,11,12$ ve 13 'de gösterilmiştir.

Tablo 10. Augmented Dickey Fuller Birim Kök Testi Sonuçları (Düzey)

Sabit Terimli

\begin{tabular}{|l|c|c|c|c|}
\hline ADF (Düzey) & t-istatistik & Olasılık & t-istatistik & Olasılık \\
\hline LOGXU30 & -0.9697 & 0.7578 & -2.3037 & 0.4247 \\
\hline LOGMXEF & -0.4476 & 0.8929 & -2.5685 & 0.2958 \\
\hline
\end{tabular}

Tablo 11. Philips-Peron Birim Kök Testi Sonuçları (Düzey)

Sabit Terimli

\begin{tabular}{|l|c|l|c|c|}
\hline Phillips-Perron (Düzey) & t-istatistik & Olasılık & t-istatistik & Olasılık \\
\hline LOGXU30 & -0.9362 & 0.7691 & -2.3135 & 0.4196 \\
\hline LOGMXEF & -0.4507 & 0.8923 & -2.7954 & 0.2053 \\
\hline
\end{tabular}

Tablo 12. Augmented Dickey Fuller Birim Kök Testi Sonuçları ( 1. fark)

Sabit Terimli

Sabit Terim ve Trendli

\begin{tabular}{|l|l|l|l|l|}
\hline ADF (1. fark) & t-istatistik & Olasılık & t-istatistik & Olasilı \\
\hline$D($ LOGXU30) & -8.6097 & 0.0000 & -8.5404 & 0.0000 \\
\hline$D($ LOGMXEF) & -7.1320 & 0.0000 & -7.0708 & 0.0000 \\
\hline
\end{tabular}


H. Ozturk

Tablo 13. Philips-Peron Birim Kök Testi Sonuçları (1. fark)

Sabit Terimli

Sabit Terim ve Trendli

\begin{tabular}{|l|c|l|c|c|}
\hline Phillips-Perron (1. fark) & t-istatistik & Olasılık & t-istatistik & Olasılık \\
\hline$D($ LOGXU30) & -8.5884 & 0.0000 & -8.5233 & 0.0000 \\
\hline$D($ LOGMXEF) & -7.1349 & 0.0000 & -7.0698 & 0.0000 \\
\hline
\end{tabular}

Tablolardan anlaşıldığı üzere seriler ADF ve PP birim kök testi sonuçlarına göre düzey bazında durağan değildir ancak serilerin birinci farkları alınarak yapılan testlerde serilerin durağan olduğu görülmektedir. Bundan sonra VAR analizi yapılıp optimal gecikme uzunluğu belirlendikten sonra, Johansen eşbütünleşme analizi yapılmıştır. Tablo 14 VAR analizi sonuçlarını göstermektedir.

Tablo 14. VAR Gecikme Uzunluğu Seçim Kriteri

\begin{tabular}{|c|c|c|c|c|c|}
\hline $\begin{array}{c}\text { Gecikme } \\
\text { Uzunluğu }\end{array}$ & LR & FPE & AIC & SC & HQ \\
\hline 0 & NA & $3.66 \mathrm{e}-05$ & -4.5400 & -4.4612 & -4.5103 \\
\hline 1 & $213.5648 *$ & $3.38 \mathrm{e}-07 *$ & $-9.2235 *$ & $-8.9873 *$ & $-9.1346 *$ \\
\hline 2 & 2.9617 & $3.74 \mathrm{e}-07$ & -9.1238 & -8.7302 & -8.9757 \\
\hline 3 & 8.4961 & $3.60 \mathrm{e}-07$ & -9.1660 & -8.6149 & -8.9586 \\
\hline 4 & 2.0924 & $4.06 \mathrm{e}-07$ & -9.0509 & -8.3423 & -8.7842 \\
\hline 5 & 3.3356 & $4.42 \mathrm{e}-07$ & -8.9733 & -8.1073 & -8.6474 \\
\hline 6 & 1.6886 & $5.05 \mathrm{e}-07$ & -8.8527 & -7.8293 & -8.4676 \\
\hline 7 & 4.3190 & $5.32 \mathrm{e}-07$ & -8.8175 & -7.6366 & -8.3731 \\
\hline 8 & 5.6636 & $5.34 \mathrm{e}-07$ & -8.8361 & -7.4977 & -8.3324 \\
\hline
\end{tabular}

Tablo 14' den anlaşıldığı üzere tüm kriterlere göre optimal gecikme uzunluğu bir olarak belirlenmiştir.

Kriz öncesi optimal gecikme uzunluğu sıfir olarak yapılan Johansen eşbütünleşme testi sonuçları aşağıdaki Tablo 15'de gösterilmiştir.(Eviews5, usersguide: 727).

Tablo 15. Johansen Eşbütünleşme Testi Sonuçları (Gecikmesiz)

\begin{tabular}{|c|c|c|c|c|c|c|}
\hline Ho & $\mid \begin{array}{l}\text { iz (Trace) } \\
\text { İstatistiği }\end{array}$ & $\begin{array}{c}0.05 \text { Kritik } \\
\text { Değer }\end{array}$ & Olasılık & $\begin{array}{l}\text { Maksimum } \\
\text { Özdeğer } \\
\text { İstatistiği }\end{array}$ & $\begin{array}{c}0.05 \text { Kritik } \\
\text { Değer }\end{array}$ & Olasılık \\
\hline Koentegre Vektör Yoktur $(r=0)$ & 5.301158 & 15.49471 & 0.7761 & 5.136000 & 14.26460 & 0.7246 \\
\hline En Çok 1 Koentegre Vektör Vardır. $(r \leq 1)$ & 0.165158 & 3.841466 & 0.6844 & 0.165158 & 3.841466 & 0.6844 \\
\hline
\end{tabular}


BIST 30 Endeksi ile MSCI Gelişmekte Olan Piyasalar Endeksinin Küresel Kriz Öncesi ve Sonrası Eşbütünleşme Analizi

Kriz öncesi dönemde hem iz (trace) istatistiği hem de maksimum özdeğer istatistiğine göre seriler arasında herhangi bir eşbütünleşme yoktur. XU30 endeksi ve gelişmekte olan piyasalar MXEF endeksinin krizden önceki dönemde beraber hareket etmediği tespit edilmiştir.

\subsection{Küresel Kriz Sonrası Dönem İçin Yapılan Analizler}

Kriz sonrası dönem için birim kök testi sonuçları Tablo 16, 17, 18 ve Tablo 19'da gösterilmiştir.

Tablo 16. Augmented Dickey Fuller Birim Kök Testi Sonuçları (Düzey)

\begin{tabular}{|l|c|c|c|c|}
\multicolumn{3}{c}{ Sabit Terimli } & \multicolumn{3}{c|}{ Sabit Terim ve Trendli } \\
\hline ADF (Düzey) & t-istatistik & Olasılık & t-istatistik & Olasılık \\
\hline LOGXU30 & -0.9721 & 0.7615 & -2.6425 & 0.2626 \\
\hline LOGMXEF & -2.9118 & 0.0470 & -2.8680 & 0.1767 \\
\hline
\end{tabular}

Tablo 17. Philips-Peron Birim Kök Testi Sonuçları (Düzey)

Sabit Terimli

\begin{tabular}{|l|c|c|c|c|}
\hline Phillips-Perron (Düzey) & t-istatistik & Olasılık & t-istatistik & Olasılık \\
\hline LOGXU30 & -1.0032 & 0.7506 & -2.7346 & 0.2249 \\
\hline LOGMXEF & -2.7608 & 0.0671 & -2.7208 & 0.2303 \\
\hline
\end{tabular}

Tablo 18. Augmented Dickey Fuller Birim Kök Testi Sonuçları (1. fark)

Sabit Terimli

Sabit Terim ve Trendli

\begin{tabular}{|l|c|c|c|c|}
\hline ADF (1. fark) & t-istatistik & Olasılık & t-istatistik & Olasilık \\
\hline$D($ LOGXU30) & -10.7003 & 0.0000 & -10.7148 & 0.0000 \\
\hline$D($ LOGMXEF) & -8.7256 & 0.0000 & -8.7326 & 0.0000 \\
\hline
\end{tabular}

Tablo 19. Philips-Peron Birim Kök Testi Sonuçları (1. fark)

Sabit Terimli

Sabit Terim ve Trendli

\begin{tabular}{|l|c|c|c|c|}
\hline Phillips-Perron (1. fark) & t-istatistik & Olasılık & t-istatistik & Olasılık \\
\hline D(LOGXU30) & -10.6997 & 0.0000 & -10.7141 & 0.0000 \\
\hline D(LOGMXEF) & -8.8009 & 0.0000 & -8.7959 & 0.0000 \\
\hline
\end{tabular}


Tablolardan anlaşıldığı üzere seriler ADF ve PP birim kök testi sonuçlarına göre düzey bazında durağan değildir ancak serilerin birinci farkları alınarak yapılan testlerde serilerin durağan olduğu görülmektedir. Kriz sonrası dönem için yapılan VAR analizi sonuçları da Tablo 20'de gösterilmektedir. Tablo 20 'deki sonuçlara göre optimal gecikme uzunluğu FPE ve AIC kriterlerine göre dört olarak belirlenmiştir.

Tablo 20. VAR Gecikme Uzunluğu Seçim Kriteri

\begin{tabular}{|c|c|c|c|c|c|}
\hline Gecikme Uzunluğu & LR & FPE & AIC & SC & HQ \\
\hline $\mathbf{0}$ & NA & $7.24 \mathrm{e}-05$ & -3.8573 & -3.8087 & -3.8376 \\
\hline $\mathbf{1}$ & 523.3066 & $6.40 \mathrm{e}-07$ & -8.5868 & $-8.441183^{*}$ & -8.5277 \\
\hline $\mathbf{2}$ & 6.9389 & $6.02 \mathrm{e}-07$ & -8.6472 & -8.4044 & $-8.5487^{*}$ \\
\hline $\mathbf{3}$ & $14.0993^{*}$ & $6.05 \mathrm{e}-07$ & -8.6418 & -8.3020 & -8.5039 \\
\hline $\mathbf{4}$ & 8.5252 & $5.99 \mathrm{e}-07^{*}$ & $-8.6532^{*}$ & -8.2163 & -8.4759 \\
\hline $\mathbf{5}$ & 3.8385 & $6.20 \mathrm{e}-07$ & -8.6197 & -8.0857 & -8.4031 \\
\hline $\mathbf{6}$ & 5.1622 & $6.32 \mathrm{e}-07$ & -8.6004 & -7.9694 & -8.3444 \\
\hline $\mathbf{7}$ & 0.0323 & $6.80 \mathrm{e}-07$ & -8.5293 & -7.8012 & -8.2339 \\
\hline $\mathbf{8}$ & 0.8298 & $7.25 \mathrm{e}-07$ & -8.4667 & -7.6414 & -8.1318 \\
\hline
\end{tabular}

Kriz sonrası dönem için üç gecikmeli olarak yapılan Johansen eşbütünleşme testi sonuçları Tablo 21 'de sunulmuştur.

Tablo 21. Johansen Eşbütünleşme Testi Sonuçları (3 Gecikmeli)

\begin{tabular}{|c|c|c|c|c|c|c|}
\hline Ho & $\begin{array}{c}\text { İz (Trace) } \\
\text { İstatistiği }\end{array}$ & $\begin{array}{c}\mathbf{0 . 0 5} \text { Kritik } \\
\text { Değer }\end{array}$ & Olasılık & $\begin{array}{c}\text { Maksimum } \\
\text { Özdeğer } \\
\text { İstatistiği }\end{array}$ & $\begin{array}{c}\mathbf{0 . 0 5} \\
\text { Kritik } \\
\text { Değer }\end{array}$ & Olasılık \\
\hline Koentegre Vektör Yoktur $(r=0)$ & 17.9256 & 15.4947 & 0.0211 & 16.9635 & 14.2646 & 0.0183 \\
\hline En Çok 1 Koentegre Vektör Vardır. $(r \leq 1)$ & 0.9621 & 3.8415 & 0.3267 & 0.9621 & 3.8415 & 0.3267 \\
\hline
\end{tabular}

Tablo 21'deki sonuçlara göre, hem iz (trace) hem de maksimum özdeğer istatistiğine göre \%5 anlam düzeyinde endeksler arasında eşbütünleşme gözükmektedir. XU30 ve MXEF endekslerinin küresel kriz sonrası uzun dönemde birlikte hareket ettikleri tespit edilmiştir.

\section{Sonuç}

Uluslararası yatırımcılar, portföy ve fon yöneticileri için farklı ülkelere yatırım yapıp çeşitlendirme yapmak ve riski azaltmak oldukça önemlidir. Çeşitlendirme yapmanın faydası ancak farklı piyasalar beraber hareket etmeyip bağımsız hareket ettikleri takdirde olabilir. Ancak, son yıllarda yaşanan küreselleşme ile birlikte farklı ülkelerdeki piyasalar birbirine daha çok entegre olmuştur ve beraber hareket etme eğilimleri artmıştır.

Bu çalışmada, Borsa İstanbul'daki XU30 endeksinin gelişmekte olan piyasalar endeksi olan MXEF endeksi ile uzun dönemli ilişkisi Johansen eşbütünleşme analizi ile incelenmiştir. Türkiye'nin de dahil olduğu Morgan Stanley tarafindan hesaplanan gelişmekte olan piyasalar endeksi son zamanlarda yatrımcılar ve fon yöneticileri tarafindan sıklıkla takip edilen bir endekstir. $\mathrm{MSCl}$ endeksi gelişmekte olan piyasalarda kıyaslama ölçütü (benchmark) olarak kabul edildiğinden, bu endeksin Borsa i̇stanbul ile olan ilişkisi portföy yöneticileri 
için çok önemlidir. Aynı zamanda son küresel finansal krizin endeksler arasındaki ilişkiyi nasıl etkilediğini analiz edebilmek için tüm dönem kriz öncesi ve kriz sonrası dönemlere ayrılmıştır.

Ocak 2003 ve Temmuz 2017 dönemi için yapılan analizlerde, endekslerin uzun dönemde beraber hareket ettiği ve eşbütünleşik olduğu bulunmuştur. Tüm dönem için yapılan test sonuçları, hem iz (trace) istatistiğine göre hem de maksimum özdeğer istatistiğine göre \%10 anlamllık düzeyinde XU30 ve MXEF endekslerinde eşbütünleşme ilişkisinin mevcut olduğunu göstermektedir. Ocak 2003 ve Temmuz 2017 dönemi arasında, endeksler arasında uzun dönemli bir ilişki olduğu sonucuna varılmıştır.

Küresel finansal kriz öncesi dönem olarak seçilen Ocak 2003 - Temmuz 2007 arasında Johansen testi yapıldığında, endeksler arasında eşbütünleşme olmadığı sonucu ortaya çıkmıştır. Ancak küresel finansal krizden sonraki dönemde, her iki endeksin ilişkili ve eşbütünleşik olduğu gösterilmiştir. Küresel finansal kriz sonrası, Ağustos 2007 ve Temmuz 2017 dönemi arasında MSCl gelişmekte olan piyasalar endeksi ile Borsa İstanbul'un beraber hareket ettiği belirlenmiştir.

2003-2007 küresel finansal kriz öncesi endeksler arasında eşbütünleşmenin bulunamaması, Türkiye piyasasının gelişmekte olan piyasalarla tam olarak entegre olmadığı ve daha çok kendi iç dinamikleriye hareket ettiği anlamına gelebilir. Aynı zamanda, Türkiye 2001-2002 krizi ile beraber ekonominin daralması, enflasyon ve faizlerin çok yükselmesi ve birçok bankanın kapanmasıyla yeniden yapılandırma dönemine girmiştir. Yaşanan 2001-2002 krizi Türkiye'nin kendi iç dinamiklerinin sonucu olan bir krizdir ve bu krizle beraber Türkiye ekonomisinde yaşanan tahribatın büyük olmasından dolayı, krizin gerçek anlamda atlatılması uzun süre almıştır. Dolayısıyla bu dönemde, Borsa İstanbul'un diğer gelişmekte olan ülke borsalarıyla beraber hareket etmeyip daha çok kendi dinamikleriyle hareket ettiği söylenebilir.

Ancak son yıllardaki Türkiye ekonomisindeki olumlu gelişmeler ve finansal piyasalardaki artan küreselleşmeyle birlikte Borsa İstanbul, diğer gelişmekte olan ülke borsalarına daha çok entegre olmuştur. Küresel finansal kriz sonrasında da, Borsa İstanbul ve $\mathrm{MSCl}$ gelişmekte olan piyasalar endeksinin beraber hareket ettikleri tespit edilmiştir. Bununla beraber, uluslararası yatırımcılar için portföy çeşitlendirmesinin kısıtlı olarak faydalı olabileceği sonucu çıkarılabilir.

\section{Kaynaklar}

Akel, V. (2015). Kırılgan beşli ülkelerinin hisse senedi piyasaları arasındaki eşbütünleşme analizi. Uluslararası Yönetim iktisat ve Işletme Dergisi, 11(24): 75-96.

Ali S., Butt Z. B., \& Rehman, K.(2011). Comovement between emerging and developed stock markets: An investigation through cointegration analysis. World Applied Sciences Journal, 12(4): 395-403.

Boztosun, D., \& Çelik T. (2011). Türkiye borsasının avrupa borsaları ile eşbütünleşme analizi. Süleyman Demirel Üniversitesi Iktisadi ve Idari Bilimler Fakültesi Dergisi, 16(1): 147-162.

Bulut, Ş., \& Özdemir, A. (2012). İstanbul Menkul Kıymetler Borsası ve "Dow Jones Industrial” arasındaki ilişki: Eşbütünleşme analizi. Celal Bayar Üniversitesi i.i.B.F. Yönetim ve Ekonomi Dergisi, 19(1): 211-244.

Chou, R.Y. , Victor Ng., \& Pi, L.N. (1994). Cointegration of international stock market indices. IMF Workin Paper, No. 94/94, Ağustos 1994.

Erdinc, H., \& Milla, J. (2009). Analysis of cointegration in capital markets of France, Germany and United Kingdom. Economics \& Business Journal: Inquiries \& Perspectives, 2(1): $109-123$.

Gilmore, C.G., \& McManus, G.M. (2003). Bilateral and multilateral coıntegration properties between the German and Central European equity markets. Studies in Economics and Finance, 21(1): 40-53, https://doi.org/10.1108/eb028768.

Kasa, K. (1992). Common stochastic trends in international stock markets. Journal of Monetary Economics, 29(1): 95-124.

Kenourgios, D.F., \& Samitas, A.G. (2003). The interdependence of major European stock markets: Evidence for Greece. Spoduai, 53 (4), ss. 54-65. 
Khanna, S. (2016). Financial crisis effect on cointegration of Indian stock market with Japan and UK. International Journal of Emerging Research in Management \& Technology, 5(2): 20-26.

Narayan, P. K., \& Russell, S. (2004). Modelling the linkage between the Australian and G7 stock markets: Common stochastic trends and regime shifts. Applied Financial Economics, 14: 991-1004.

Nashier, T. (2015). Financial integration between BRICS and developed stock markets. International Journal of Business and Management Invention, 4(1): 65-7.

Sevüktekin, M., \& Nargeleçekenler, M. (2008). Türkiye ve Amerika'daki hisse senedi piyasaları arasındaki dinamik ilişkinin belirlenmesi. Finans Politik ve Ekonomik Yorumlar Dergisi, 45(520): 15-23.

Vuran, B. (2010). IMKB100 endeksinin uluslararası hisse senedi endeksleri ile ilişkisinin eşbütünleşim analizi ile belirlenmesi. İstanbul Üniversitesi İ̧̧letme Fakültesi Dergisi, 39(1): 154-168.

Worthington, A., C., \& Higgs, H. (2007). Assesing financial Integration in European Union equity markets, 1990-2006: Panel Unit Root and Multivariate Cointegration and Causality Evidence. University of Wollongong, School of Accounting and Finance Working Paper Series, No:07/10, ss. 1-20.

Yıldız, A., \& Aksoy, E.E. (2014). Morgan Stanley Gelişmekte Olan Borsa Endeksi ile BIST Endeksi arasındaki eşbütünleşme ilişkisinin analiz edilmesi. Atatürk Üniversitesi Iktisadi ve Idari Bilimler Dergisi, 28(1): 119

Yüksel A., Yüksel A., Erol Ü., \& Öztürk H. (2017). The impact of the global financial crisis on the co-integration relationship between reit and stock markets: A dynamic co-integration approach. International Journal of Economics and Finance, 9(7): 86-98.

https://www.msci.com/documents/1296102/1362201/MIS-EM.pdf/050ce035-a9c8-4c31-a4d9e826cedd1ea0 (Erişim Tarihi, 1 Ağustos 2017).

http://public.econ.duke.edu/pub/burmeister/EViews/EViews_5_Users_Guide.pdf (Erişim Tarihi, 10 Kasım 2017). 
This Page Intentionally Left Blank 